\title{
Trade Reforms, Macroeconomic Performance and Welfare in Malawi
}

\author{
Harold Ngalawa \\ Lecturer, School of Accounting, Economics \& Finance, University of KwaZulu-Natal, \\ Westville Campus, Durban 4000, Republic of South Africa. \\ Emails: ngalawa@ukzn.ac.za/hngalawa@yahoo.co.uk
}

\section{Doi:10.5901/mjss.2014.v5n3p307}

\begin{abstract}
This paper sets out to show efficiency gains and/or losses of trade reforms in Malawi using simulation experiments in a Computable General Equilibrium (CGE) model. Among others, the study shows that a 50 percent tariff cut coupled with fixed government savings has the same impact on selected macroeconomic variables when capital is mobile as when it is activity specific. When capital is activity-specific, the tariff cut has a positive impact on labour income in the non-agricultural sector and a similar impact on capital income in commercial agriculture. Overall labour income in the agricultural sector is unaffected while the impact on capital income in small scale agriculture and non-agriculture sectors is negative. When capital is mobile, the tariff cut leads to a fall in the capital income in small scale agriculture. The study further shows that doubling foreign aid to Malawi increases consumption and adversely affects the production side of the economy.
\end{abstract}

Keywords: computable general equilibrium, trade reforms, welfare

\section{Introduction}

Malawi is one of the poorest countries in the world. The country has a narrow economic base, a low per capita income level, a high population density, a landlocked status with prohibitive costs of external trade, few known mineral resources, and high rates of unemployment and infant mortality (Malawi Government and the United Nations, 1993). The country attained independence in 1964 and managed to achieve high real gross domestic product (GDP) growth rates estimated at 6 percent between 1964 and 1970 and 7 percent between 1971 and 1979. However, in the early 1980s, the external environment deteriorated and the Malawi economy went into a deep recession, which persisted through the 1980s. Intensification of civil war in Mozambique with a subsequent flooding of refugees into Malawi and disruption of Malawi's cost effective rail route to the Mozambican sea ports of Beira and Nacala, the 1979 oil crisis, and drought in 1980, were some of the factors that led to the recession. Failure of the economy to adjust to these shocks revealed structural weaknesses in the design of the country's macroeconomic framework. The country embarked on trade policy reforms in 1980-81 as part of International Monetary Fund's (IMF) supported Structural Adjustment Programs (SAPs) that were specifically designed to bail the country out of a looming economic crisis.

The reforms were primarily aimed at diversifying the export base, encouraging efficient import substitution, ensuring appropriate price and income policy, expanding the role of the private sector in the marketing of smallholder crops, increasing efficiency and improving incomes of smallholder farmers, increasing efficiency of land use and improving the macroeconomic environment (Chirwa, 2004). The trade policies were mainly concerned with removing barriers to international trade and these included elimination of import and export licensing, reduction of tariffs and surtax rates and introduction of export incentives. In addition to the active exchange rate policy since 1982, government also reduced the scope of import and export licensing in 1989; abolished the negative list of imported commodities in 1994; provided for additional tax incentives for the exportation of non-traditional agricultural products under the Export Incentives Act and Investment Promotion Act in 1992; abolished all licensing requirements on imports and exports except for items related to health, security, and environmental considerations in 1997; reduced the maximum tariff on imports from 70 percent in 1988 to 25 percent in 1998; and carried out a phased reduction in tariff rates and base surtax rates from 1989 (Chirwa, 2004).

The country has also implemented trade policies in line with specified international trade agreements. Examples include the Malawi-South Africa non-reciprocal free trade agreement since 1990; the Malawi-Zimbabwe reciprocal trade agreement since 1995; the Common Market for Eastern and Southern Africa (COMESA) free trade area ratified in 2000; and the Southern African Development Community (SADC) Trade Protocol in 2001. These regional agreements 
introduced duty free access of products on a reciprocal basis among member states except for the SADC Trade Protocol, which placed import restrictions on imported livestock commodities such as eggs and chicken meat under the protocol premise of infant industry protection. Malawi is also a member of the World Trade Organization (WTO) (since 1995), the European Union - African Caribbean and Pacific (EU-ACP) countries' Cotonou agreement, the European Union Everything but Arms (EBA) non-reciprocal multilateral agreement and the African Growth Opportunity Act nonreciprocal multilateral agreement with the United States of America (Chirwa, 2004) ${ }^{1}$.

While the country has been very active in its implementation of trade reforms, the impact of these reforms on economic activity and welfare in Malawi is yet to be understood. It is, therefore, the need to contribute towards attaining this understanding that has motivated this study. The paper presents simulation experiments of trade reform scenarios and attempts to show efficiency gains/losses of the simulated trade reforms using a Computable General Equilibrium (CGE) model. A similar study was carried out by Mbabazi (2002), who also used a CGE model to analyse the short-run welfare effects of tariff liberalisation in Uganda. While Mbabazi's analysis considered the impact of tariff cuts on Uganda's GDP as an indicator of overall macroeconomic performance in the country, this study investigates how tariff cuts would affect a variety of macroeconomic aggregates, thus making our study more robust.

The rest of the paper is organised as follows. Section 2 presents the simulation experiments of hypothetical trade reforms in Malawi. Three trade reform experiments are investigated, namely, a 50\% cut in tariffs coupled with fixed government savings and activity specific capital; a 50\% cut in tariffs together with fixed government savings and mobile capital; and a 100\% increase in foreign savings with default closures. The section also discusses the impact of the trade reforms on macroeconomic performance and households in Malawi. Section 5 concludes the paper.

\section{Simulation Experiments}

In order to understand the impact of tariff cuts and changes in foreign aid on the economy, we carry out simulation experiments using a CGE model for Malawi. The primary database that is used is a 1998 Social Accounting Matrix (SAM) constructed from the 1997-1998 Integrated Household Survey for Malawi (see Lofgren et al, 2001; Chulu and Wobst, 2000). Three trade reform experiments are carried out, namely:

Scenario 1: 50\% cut in tariffs + fixed government savings + activity specific capital (TARCUT1)

Scenario 2: $50 \%$ cut in tariffs + fixed government savings + mobile capital (TARCUT2)

Scenario 3: $100 \%$ increase in foreign savings with default closures (FSAVINCR)

\subsection{Impact of Trade Reforms on Macroeconomic Performance}

In this section, we consider the impact of the three trade reform scenarios on selected macroeconomic variables. Simulations of the three scenarios are presented in Table 1. One interesting observation in the simulation results is that the selected macroeconomic aggregates tend to move together in the same direction and with more or less the same magnitudes for each of the first two scenarios. Thus, a 50\% tariff cut coupled with fixed government savings has the same impact on macroeconomic aggregates when capital is mobile as well as when it is activity specific. Against the assumption that government savings is fixed, a $50 \%$ tariff cut translates to a reduction in government expenditure equivalent to the value of the revenue loss from the tariff cut ${ }^{2}$ and a reduction in investment (INVGDP) (expressed as a ratio of nominal GDP) (see Table 1). As expected, tariff revenue (TARGDP) (expressed as a ratio of GDP) goes down. The real exchange rate (REXR) shows an appreciation of the local currency vis-à-vis other trading currencies, which effectively leads to an increase in imports (QMTOT), trade deficit (TRDEFGDP), real household consumption (QHTOT) and real absorption (QABSTOT) and a reduction in private savings (PRVSAVGDP).

A $100 \%$ increase in foreign savings is on the whole detrimental to the economy. Total real exports (QETOT), purchasing power parity (PPP) real exchange rate (REXR), nominal exchange rate (NXER), domestic (non-tradable) price index (PDIND) investment as a percentage of nominal GDP (INVGDP) and private savings as a percentage of nominal GDP (PRVSAVGDP) decline by 4.9\%, 1.4\%, 1.0\%, 1.0\%, 0.1\% and 2.1\%, in that order. This trial, however, increases real absorption (QABSTOT) by 1.9\%, real household consumption (QHTOT) by $4.0 \%$, total real imports

\footnotetext{
${ }^{1}$ For a detailed presentation of the trade reforms, see "Chirwa, E. (2004). Effects of Economic and Trade Policy Reforms on Food Security in Malawi. Wadonda Consult Working Paper WC/02/04."

${ }^{2}$ From the national income accounting identity, assuming that income $(\mathrm{Y})$ can be broken down into consumption $(C)$, savings $(S)$ and tax (T) (i.e. $Y=C+S+T)$, it can be shown that $(S+(T-G)+(M-X)=I)$ where $(T-G)$ is government savings. With a $50 \%$ tariff cut and assuming $(T$ $\mathrm{G}$ ) remains constant, then $\mathrm{G}$ must go down proportionately.
} 
(QMTOT) by 1.3\%, foreign savings measured as a percentage of nominal GDP (FSAVGDP) by 2.0\%, and trade deficit as a percentage of nominal GDP (TRDEFGDP) by $1.8 \%$ (see Table 1).

Table 1: Impact of Trade Reforms on Selected Macroeconomic Variables

\begin{tabular}{|l|c|c|c|c|}
\hline \multicolumn{1}{|c|}{ Variable } & Base & $\begin{array}{c}\text { Scenario 1 } \\
\text { (TARCUT1) }\end{array}$ & $\begin{array}{c}\text { Scenario 2 } \\
\text { (TARCUT 2) }\end{array}$ & $\begin{array}{c}\text { Scenario 3 } \\
\text { (FSAVINCR) }\end{array}$ \\
\hline QABSTOT & 11954.2 & 0.3 & 0.3 & 1.9 \\
\hline QHTOT & 5692.0 & 0.6 & 0.6 & 4.0 \\
\hline QETOT & 3049.8 & 6.0 & 6.1 & -4.9 \\
\hline QMTOT & 5257.8 & 4.3 & 4.3 & 1.3 \\
\hline REXR & 100.0 & -0.1 & & -1.4 \\
\hline NEXR & 100.0 & 1.6 & 1.5 & -1.0 \\
\hline PDIND & 100.0 & 1.6 & 1.5 & -1.0 \\
\hline INVGDP & 14.1 & -0.1 & -0.1 & -0.1 \\
\hline PRVSAVGDP & 28.6 & -0.2 & -0.2 & -2.1 \\
\hline FSAVGDP & 2.0 & & & 2.0 \\
\hline TRDDEFGDP & 21.6 & -1.9 & -1.9 & 1.8 \\
\hline GSAVGDP & -16.5 & 0.1 & 0.1 & \\
\hline TARGDP & 4.6 & -2.1 & -2.1 & \\
\hline YTAXGDP & 7.3 & 2.1 & 2.1 & \\
\hline
\end{tabular}

It is imperative to note that the sectors that are adversely affected are on the production side of the economy while the sectors that are positively affected are mainly on the consumption end. We can safely argue, therefore, that a 100\% increase in Malawi's foreign savings (coming in the form of foreign aid) will hurt the economy's production side by initially adversely affecting the country's exchange rate. Table 1 shows that there will be an appreciation of the domestic currency vis-à-vis foreign currencies both in terms of PPP real exchange rate and nominal exchange rate. This reduces the competitiveness of domestic goods on the international market (exports are adversely affected); investment (measured as a percentage of nominal GDP) goes down following a cut in the production of export goods as well as the fact that imported investment goods become expensive in local currency terms as a result of the local currency appreciation; the price of domestic non-tradable goods is depressed as people's preferences tilt towards imported substitutes, which become cheaper due to the local currency appreciation; and in view of the fact that consumption is being encouraged (because of the currency appreciation), private savings go down. It can safely be concluded, therefore, that a $100 \%$ increase in foreign aid has a Dutch Disease effect on the economy of Malawi. This is evidenced by the observed reduction in production of traditional commodities in favour of consumption.

\subsection{Impact of Trade Reforms on Households}

The impact of two shocks is analysed in this section:

(i) change in international terms of trade - since a reduction in tariffs leads to changes in relative prices which impacts on the rest of the economy.

(ii) increase in foreign capital inflow or foreign savings.

Specifically, we investigate the micro-level effects of tariff reduction and shocks to foreign capital inflow. A reduction in tariff rates represents a decrease in the world price of imported goods. This implies that for the same amount of exports, the country can now buy more imports. This distorts the terms of trade, adversely affecting domestic import competing sectors. Scenario 1, which is a $50 \%$ reduction in tariffs with fixed government saving and activity-specific capital is seen to have a positive impact on labour income in non-agricultural sector and capital income in commercial (large scale) agriculture (about 0.1 percent) (see Table 2 for details).

Table 2: Disaggregated Factor Income Distribution (\% Shares)

\begin{tabular}{|l|c|c|c|c|}
\hline \multicolumn{1}{|c|}{ Variable } & Base & TARCUT1 & TARCUT2 & FSAVINCR \\
\hline AGLAB & 16.7 & & 0.1 & -0.4 \\
\hline NALAB & 42.4 & 0.1 & & 0.3 \\
\hline
\end{tabular}




\begin{tabular}{|l|c|c|c|c|}
\hline CAPITAS & 5.4 & -0.2 & -0.2 & -0.1 \\
\hline CAPITAL & 1.6 & 0.1 & 0.2 & -0.1 \\
\hline CAPIT & 33.9 & -0.1 & & 0.3 \\
\hline TOTAL & 100.0 & & & \\
\hline
\end{tabular}

Capital income in small scale agriculture and non-agriculture sectors is adversely affected i.e. declines by 0.2 percent and 0.1 percent, respectively. The tariff reduction makes the conventional domestic (primary) products cheaper and since very little capital is available in small scale agriculture, the only mobile resource, labour, moves into alternative employment. The positive impact on capital in large scale agriculture is probably due to the availability of cheaper imported production inputs such as tractors, ploughs and other equipment. Since there is increased productivity in large scale agriculture, overall labour income in the agricultural sector remains unaffected in this scenario.

Scenario 2, the simulation in which a 50\% reduction in tariffs with fixed government saving and mobile capital is examined reveals that the change in relative prices leads to a fall in the capital income in small scale agriculture. Since the terms of trade are now favouring large scale agriculture, there is increased investment by about 0.2 per cent. Capital moves into the productive large scale agricultural sector leaving both the capital income in non-agriculture sector and the associated level of income (labour) unchanged. The increased investment in commercial agriculture leads to a higher demand for labour hence total agricultural labour income increases by 0.1 per cent.

Scenario 3 examines the impact of a 100\% increase in foreign savings occurring due to additional access to world financial markets or foreign aid inflows. This leads to an increase in domestic prices relative to world prices. The change in relative prices hurts the tradable agricultural sector as shown not only by the decline in capital income in both small and large scale agricultural sectors ( 0.1 per cent in each case) but also a 0.4 per cent reduction in agricultural labour income. This is in contrast to the expansion of the non- agriculture sector in terms of capital and labour income (0.3 per cent respectively). This contraction of the tradable sector relative to the non-tradable goods demonstrates the presence of Dutch disease.

There is a close linkage between sectors and the market for factors of production. The role of these interactions is significant in terms of welfare outcomes (see Table 3). In scenario 1, since trade liberalization hurts capital that is employed in the large scale agriculture and non-agriculture sectors, the urban high income households which rely heavily on returns to capital are adversely affected as shown by a 1.1 per cent reduction in real household consumption. Households which rely less on capital returns are better off since there are no capital losses suffered. Rural high income households' real consumption increases by 1.6 per cent in response to the positive impact of trade liberalization on capital in large scale agriculture and non-agricultural labour income.

Table 3: Disaggregated Real Household Consumption

\begin{tabular}{|l|c|c|c|c|}
\hline \multicolumn{1}{|c|}{ Variable } & Base & TARCUT1 & TARCUT2 & FSAVINCR \\
\hline URBLOW & 1013.1 & 0.8 & 0.6 & 4.2 \\
\hline URBHIGH & 1525.4 & -1.1 & -1.0 & 5.2 \\
\hline RURLOW & 2104.4 & 1.3 & 1.3 & 3.0 \\
\hline RURHIG & 1049.0 & 1.6 & 1.5 & 4.0 \\
\hline TOTAL & 5692.0 & 0.6 & 0.6 & 4.0 \\
\hline
\end{tabular}

Scenario 2 in which capital income in large scale agriculture rises by 0.2 per cent leads to a 0.1 per cent improvement in real consumption for urban high income households, possibly due to increased returns on their investments. Rural low income households are seen to be unaffected irrespective of the assumption made about capital mobility. Urban low income and rural high income households experience slight reductions in real consumption ( 0.2 and 0.1 per cent respectively). Since both labour and capital incomes in the non-agriculture sector are unaffected, the change in relative prices as a result of liberalization means that these households have to purchase goods at a higher price with a given income i.e. real consumption declines.

Scenario 3 shows that a doubling of foreign savings unambiguously results in higher welfare across households as measured in terms of real household consumption. Due to the expansion of the non-agriculture sector owing to increased savings, the urban high income households which are the major investors in the sector get the highest returns and thus have the highest real consumption. They are followed by urban low income and rural high income households respectively. Although capital income in small scale agriculture declines as a consequence of increased foreign savings, rural low income households' real consumption still rises by 3.0 per cent. This might be probably due to the fact that 
agricultural production is now reduced to a sector that simply provides raw materials for the booming non- agriculture sector. This implies that the country can more than offset its import bill and hence real consumption may improve as seen in this experiment.

\section{Summary and Conclusion}

The paper employs a CGE model to illustrate efficiency gains/losses of trade reforms in Malawi using simulations drawn from a hypothetical case of trade reform scenarios. The paper reveals some very interesting issues. First, it is established that a $50 \%$ tariff cut coupled with fixed government savings has the same impact on macroeconomic aggregates when capital is mobile as when it is activity specific. The impact on labour income in the non-agricultural sector, however, is positive when capital is activity specific; and it is negative on capital income in non-agriculture and small scale agriculture. Similarly, the impact on capital income in commercial agriculture is positive when capital is activity specific whileas when capital is mobile, the impact of capital income in small scale agriculture is negative. Notwithstanding the increased productivity in large scale agriculture, overall labour income in the agricultural sector is unaffected. As expected, some macroeconomic aggregates are adversely affected while others are positively affected by the tariff cuts, underscoring Mbabazi's caution that 'it would be misleading to argue that trade liberalisation appears detrimental to growth' (Mbabazi, 2002, p.13).

The study further finds that a (100\%) increase in foreign aid adversely affects the production side of the economy while boosting the consumption side. We argue, therefore, that a $100 \%$ increase in foreign aid to Malawi has a Dutch Disease effect on the economy. Further illustrating the Dutch Disease, we observe that the doubling of foreign aid hurts the tradable agricultural sector but leads to an expansion of the non-tradable sector. On the whole, we observe that urban high income and rural high income households are affected differently by different indicators. This underscores the fact that the Malawi government should avoid putting in place policies that are broad generalisations on how households may be affected by trade liberalisation. Rather, policies should be income group-specific and distinct for the urban or rural sectors.

\section{References}

Chirwa, E. (2004). Effects of Economic and Trade Policy Reforms on Food Security in Malawi. Wadonda Consult Working Paper No. WC/02/04.

Chulu, O. and Wobst, P. (2000). A 1998 Social Accounting Matrix for Malawi. Collaborative Research and Capacity Strengthening for Multi-Sector Policy Analysis in Malawi and Southern Africa Project Paper No. 2. Washington, D.C.: International Food Policy Research Institute.

Devarajan S. and D. van der Mensbrugghe (2000). Trade reform in South Africa: Impact on Households. World Bank Working Paper. Wahington DC.: World Bank.

Hertel T. and Reimer, J. (2004). Predicting the Poverty Impacts of Trade Reform. World Bank Policy Research Working Paper No. 3444.

Lofgren, H., Chulu, O., Sichinga, O., Simtowe, F., Tchale, H., Tseka, R. and Wobst, P. (2001). External Shocks and Domestic Poverty Alleviation: Simulations with a CGE Model of Malawi, International Food Policy Research Institute, Trade and Macroeconomics Division Discussion Paper.

Malawi Government/United Nations (1993). Situation Analysis of Poverty in Malawi. Lilongwe: Ministry of Finance.

Mbabazi, J. (2002). A CGE Analysis of the Short-Run Welfare Effects of Tariff Liberalisation in Uganda, World Institute for Development Economic Research (WIDER) Discussion Paper No. 2002/114. 